\title{
Antibacterial and anti-biofilm activity of cinnamon essential oil and eugenol
}

\author{
Alessandra Farias Millezi ${ }^{1 *}$ (D) Karine Angélica Dalla Costa ${ }^{2}$ José Maria Oliveira $^{3}$ \\ Susana Patrícia Lopes ${ }^{3}$ Maria Olívia Pereira ${ }^{3}$ Roberta Hilsdorf Piccoli $^{4}$
}

\author{
'Instituto Federal Catarinense (IFC), Campus Concórdia, 89700-000, Concórdia, SC, Brasil. E-mail: alessandra.millezi@ifc.edu.br." Corresponding author. \\ ${ }^{2}$ Universidade Regional e Integrada do Alto Uruguai e das Missões (URI), Erechim, RS, Brasil. \\ ${ }^{3}$ Centre of Biological Engineering (CEB), Universidade de Minho, Braga, Portugal. \\ ${ }^{4}$ Universidade Federal de Lavras (UFLA), Lavras, MG, Brasil.
}

\begin{abstract}
Biofilms are responsible for most of the interference caused by microorganisms in food processing. The aim of this study was to evaluate the cinnamon (Cinnamomum zeylanicum) essential oil and eugenol sanitizer and anti-biofilm activity against biofilms. Concentrations used of essential oil were $0.0 \%$ (control) $0.12 \% ; 0.48 \% ; 0.96 \%$ and $1.92 \%$; the amount of eugenol was $0.76 \%$. Concentrations were determined from other published studies. Number of viable cells and quantification the bacterial biomass were determined. Anti-biofilm treatment was effective in preventing the formation of biofilms. The $1.92 \%$ concentration was the most satisfactorily with Escherichia coli reduction of $5.91 \log \mathrm{CFUcm}^{-2}$ and Staphylococcus aureus reduction of $5.17 \log \mathrm{CFUcm}^{-2}(P<0.05)$ biomass of the two bacteria. Sanitizing treatment was not effective in reducing biomass. Seen this, the cinnamon and eugenol essential oil may be promising alternatives for controlling biofilms.
\end{abstract} Key words: biofilm, antimicrobial natural, food processing.

Atividade antibacteriana e anti-biofilme de óleo essencial de canela e eugenol

RESUMO: Os biofilmes são responsáveis pela maior parte da interferência causada pelos micro-organismos no processamento de alimentos. O objetivo deste estudo foi avaliar a atividade anti-biofilme do óleo essencial de canela (Cinnamomum zeylanicum) e do composto majoritário eugenol. As concentrações utilizadas de óleo essencial foram de 0,0\% (controle), 0,12\%; 0,48\%; 0,96\% e 1,92\%; a concentração de eugenol foi de 0,76\%. As concentrações foram determinadas a partir de outros estudos publicados. Determinou-se o número de células viáveis e quantificouse a biomassa bacteriana. O tratamento anti-biofilme foi eficaz na prevenção e formação de biofilmes. A concentração de 1,92\% foi satisfatória,

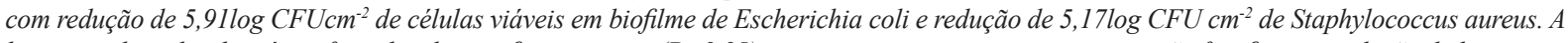
biomassa de ambas bactérias foi reduzida significativamente $(P<0,05)$, entretanto, o tratamento sanitizante não foi eficaz na redução da biomassa. Diante dos resultados, o óleo essencial de canela e eugenol podem ser alternativas promissoras no controle de biofilmes.

Palavras-chave: biofilme, antimicrobianos naturais, processamento de alimentos.

\section{INTRODUTION}

A biofilm is an assemblage of microbial cells that is irreversibly associated (not removed by gentle rinsing) with a surface and enclosed in a matrix of primarily polysaccharide material. Noncellular materials such as mineral crystals, corrosion particles, clay or silt particles, or blood components, depending on the environment in which the biofilm has developed, may also be reported in the biofilm matrix. Biofilm-associated organisms also differ from their planktonic (freely suspended) counter parts with respect to the genes that are transcribed (DONLAN, 2002). Biofilm formation in equipment and food processing surfaces causes several problems, including the corrosion of metal surfaces and crosscontamination of food products (MENON, 2016; DIAS et al., 2018). Among the pathogenic microorganisms $S$. aureus and E.coli are able to form biofilms, which are complex structures consisting of surface attached bacteria surrounded by a selfproduced extracellular polymer matrix (MILLEZI et al., 2016; FROZIET al., 2017).

Escherichia coli is one of the most versatile microorganisms reported in nature. Due to frequent precarious hygienic sanitary food production, it is common to observe them contaminating $E$. coli, as an aggravating factor, the bacteria form biofilms with ease in stainless steel surface (FROZI et al., 2017), polystyrene (MILLEZI et al., 2016) and polipropilene 
(MILLEZI et al., 2012). Staphylococcus aureus is a Gram-positive organism, mesophyll; however, studies showed that it can grow in a wide range of temperatures. $S$. aureus is able to form biofilms, which are complex structures consisting of surface-attached bacteria surrounded by a selfproduced extracellular polymer matrix. Biofilms of staphylococci on surfaces in the food industry pose a serious risk of food contamination. Additionally, $S$. aureus biofilm formation contributes to its pathogenesis in a number of conditions, such as damaged skin infections, chronic and recurrent airway infections, osteomyelitis and mastitis (KAWARAI et al., 2009; ROGERS et al., 2010).

The essential oils (EOs) of aromatic plants and their components have a wide range of applications in ethno-medicine, preservation, food flavoring and fragrances and in the perfume industries. Therefore, considerable attention has been focused on the various biological effects of naturally occurring agents (BAKKALIA et al., 2008; MILLEZI et al., 2013; SZCZEPANSKI \& LIPSKI, 2014; XIAOFENG et al., 2018). Among them are cinnamon EO and its constituents, which are known to possess various biological activities (WANG \& YANG, 2009).

Cinnamomum zeylanicum bark is widely used as a spice. It is principally employed in cooking as a condiment and flavoring material, being largely used in the preparation of some desserts, chocolate, spicy candies, tea, hot cocoa, and liqueurs. In medicine, it acts like other volatile oils and was once used as a cure for colds. It has also been used to treat diarrhea and other problems of the digestive system; C. zeylanicum bark is high in antioxidant activity (OUSSALAH et al., 2007).

Given the public health problem that these bacterial species represent, studies have been performed to identify new compounds with antibacterial activity for use in the food industry. In the current study, the C. zeylanicum EO and eugenol sanitizer and anti-biofilm activity was evaluated against $E$. coli and $S$. aureus. Biofilms on a stainless steel surface after single cultivation. Stainless steel was chosen for being one of the most utilized materials in the food industries.

\section{MATERIALS AND METHODS}

\section{Experiment execution sites}

The experiment was carried in the Universidade de Minho (Braga, Portugal), in Applied Microbiology Laboratory.

\section{Essential oils and concentrations}

Antibacterial solutions were prepared by homogenization of the EO or its constituent in sterile distilled water containing $0.5 \%(\mathrm{v} / \mathrm{v})$ Tween 80 . The solutions were prepared in test tubes and agitated vortexing for $2 \mathrm{~min}$. The EO of C. Zeylanicum leaves was purchased from Ferquima Indústria e Comércio Ltda (Vargem Grande Paulista, São Paulo, Brazil). The chemical characterization of the EO, as specified by the supplier, were: color yellow, free of impurities, density $\left(20^{\circ} \mathrm{C}\right): 1.045$, refractive index $\left(20^{\circ} \mathrm{C}\right)$ : 1.533 , main component eugenol (about 90\%). Eugenol (>93\%) was purchased from Sigma Aldrich. The EO concentrations used were $0.12 \%, 0.48 \%, 0.96 \%$ and $1.92 \%$. The amount of eugenol in the antibacterial solutions was $0.76 \%$. The concentrations were selected based on a study already performed by MILLEZI et al 2016.

\section{Bacterial species, standardization and inoculum preparation}

The microorganisms used were Escherichia coli ATCC 25922 and Staphylococcus aureus ATCC 24922 obtained from the Fundação Oswaldo Cruz (FIOCRUZ), Rio de Janeiro, Brazil. The standardization of the number of cells was determined by growth curve. Throughout the experiment, the strain was stored under refrigeration in freezing culture medium $(15 \mathrm{~mL}$ glycerol, $0.5 \mathrm{~g}$ bacteriological peptone, 0.3 of yeast extract and $0.5 \mathrm{~g}$ $\mathrm{NaCl}$, per $100 \mathrm{~mL}$ of distilled water, with the final $\mathrm{pH}$ 7.4) and stored at $-80^{\circ} \mathrm{C}$. For strain reactivation and use, an aliquot of the freezing culture medium was transferred to test tubes containing Trypticase Soy Broth (TSB, Merck, Portugal), with two subcultures at $37^{\circ} \mathrm{C}$ for $24 \mathrm{~h}$. The culture was striated in Trypticase Soy Agar (TSA, Merck, Portugal) added to Petri dishes and incubated at $37^{\circ} \mathrm{C}$ for $24 \mathrm{~h}$. Of the colonies formed on the TSA surface, some were removed and transferred into an Erlenmeyer flask containing $150 \mathrm{~mL}$ of TSB, which was incubated at $37^{\circ} \mathrm{C}$ until approximately $10^{8} \mathrm{UFCml}^{-1}$ (MILLEZI et al., 2013 with modifications).

\section{Stainless steel coupons preparation}

Stainless steel coupons AISI 304 $(0.1 \times 0.8 \times 1.8 \mathrm{~cm})$ were previously hygienized and sterilized in autoclave (MILLEZI et al., 2013). First, they were cleaned with acetone $100 \%$, rinsed with sterilized distilled water, dried and cleaned with alcohol $70 \%(\mathrm{v} / \mathrm{v})$. After that, they were washed with sterilized distilled water, dried for $2 \mathrm{~h}$ at $70^{\circ} \mathrm{C}$ and autoclaved at $12^{\circ} \mathrm{C}$ for $15 \mathrm{~min}$. 


\section{Biofilm formation, activity anti-biofilm and sanitizing}

The experimental model of biofilm

formation elaborated based on a system first used by MILLEZI et al. (2013) with modifications. In the present study, the experimental model consisted of 20 stainless steel coupons AISI $304(1 \times 10 \times 20 \mathrm{~mm})$ in erlenmeyer containing TSB. AISI 304 was chosen because it is one of the most used stainless steel.

In anti-biofilm activity, were mounted systems containing coupons, flasks, solution with essential oil, eugenol and TSB. The coupons were hung with stainless steel wire and immersed in a total volume of $40 \mathrm{~mL}$. The solution was composed of standardized bacterial suspension to $10^{8} \mathrm{CFUml}^{-1}$, sanitizing solution (essential oil, DMSO, water saline Tween 80) and TSB. For each concentration solution with essential oil and eugenol prepared an individual system. The systems were incubated for 24 hours $37^{\circ} \mathrm{C}$ and $120 \mathrm{rpm}$ and proceeded to quantification of cultivable cells in biofilms and quantification of biomass.

For activity sanitizing, biofilms were formed in systems containing coupons, flasks and TSB. The coupons were hung with stainless steel wire and immersed in TSB total volume of $40 \mathrm{~mL}$. Systems were incubated for 24 hours $37^{\circ} \mathrm{C}$ and $120 \mathrm{rpm}$. After, the coupons were removed, washed two times in sterile peptone water were placed in 12 well plates. Biofilms were exposed to the sanitizing action for 30 minutes.

\section{Quantification of cultivable cells in biofilm}

After 24 hours of cultivation, the cells adhered on stainless steel coupons were removed using ultrasonic bath. Each coupon was placed in a well of 12-well sterile plates (Orange Scientific Braine-l'Alleud, Belgium) was added $1 \mathrm{ml}$ of peptone water in each well and proceeded for 6 minutes ultrasonic bath. After this procedure, was performed a serial dilution and aliquots of $0.1 \mathrm{~mL}$ were removed and the number of viable cells determined by Eosin Methylene Blue Agar (EMB) to count E. coli and mannitol agar for $S$. aureus, using the technique of microdrop. The drop plate (DP) method was used to determine the number of viable suspended bacteria, less time and effort are required to dispense the drops onto an agar plate than to spread an equivalent total sample volume into the agar (HERIGSTAD et al., 2001). Dishes were incubated at $37^{\circ} \mathrm{C} / 24$ hours. After this period, took place on plate count and the values were expressed in total number of colony forming units (CFUs) per unit area $\left(\log \mathrm{CFUcm}^{-2}\right)$. All assays were performed in three separate occasions.
Biomass quantification by crystal violet staining

Biomass of biofilms were quantified by

Crystal Violet (CV) (STEPANOVIC'et al., 2000). For fixation of the adhered cells and biofilms the coupons stainless steel coupons were added in sterile 12-well plates (Orange Scientific, Braine1'Alleud, Belgium), $2 \mathrm{~mL}$ of $99 \%$ methanol (Vaz Pereira, Portugal) was added to each well, after $15 \mathrm{~min}$ the methanol was removed and the coupons were allowed to dry about $25^{\circ} \mathrm{C}$. Then, $2 \mathrm{~mL}$ of crystal violet stain $(\mathrm{CV} ; 1 \% \mathrm{v} / \mathrm{v})$ (Merck, Portugal) were added to all wells. After $5 \mathrm{~min}$, excess of $\mathrm{CV}$ was removed and the coupons were washed in water. Finally, $1 \mathrm{~mL}$ of acetic acid (33\% v/v) (Pronalab, Portugal) were added to all wells to dissolve the $\mathrm{CV}$ stain and the absorbance was measured at $570 \mathrm{~nm}$. The classification follows the parameters according to the values of Optical Density (OD): OD control $<\mathrm{OD} \leq 2 \mathrm{OD}$ control, weakly adherent/ weak biofilm producer; $2 \mathrm{xOD}$ control $\angle \mathrm{OD} \leq 4 \mathrm{xOD}$ control, moderately adherent/moderate biofilm producer; 4xODc $<\mathrm{OD}$, strongly adherent/strong biofilm producer; where OD is optical density of the negative control and OD control is the cut-off OD value defined as three standard deviation values above the mean OD of the negative control. All assays were performed in triplicate and on three separate occasions.

\section{Statistical analysis}

Data were analyzed with GraphPad Prism ${ }^{\circledR}$ One-way ANOVA (Bonferroni) tests were performed and $\mathrm{P}<0.05$ was considered significant.

\section{RESULTS AND DISCUSSION}

According to the parameters used to classify the formation of biofilms, by biomass analysis (STAPANOVIC et al., 2000), S. aureus and $E$. coli adhered moderately in 24 hours of culture; however, PARIZZI et al. (2004) considered biofilm, when the number of adhered cells oscillates between $10^{4}$ and $10^{5} \mathrm{UFC} / \mathrm{cm}^{2}$ in the present study, results oscillated between $10^{6}$ and $10^{7} \mathrm{UFC} / \mathrm{cm}^{2}$, being higher than this parameter.

Treatments anti-biofilm eugenol and $C$. zeylanicum EO treatments anti-biofilm were effective in preventing the formation of bacterial communities on the surface of stainless steel coupons. Significant reductions $(\mathrm{P}<0.05)$ were achieved with the eugenol and all EO concentrations. Eugenol reduced $E$. coli in $3.65 \log \mathrm{CFUcm}^{-2}(56.85 \%)$, the concentration of $1.92 \%$ was the most satisfactorily with a reduction 

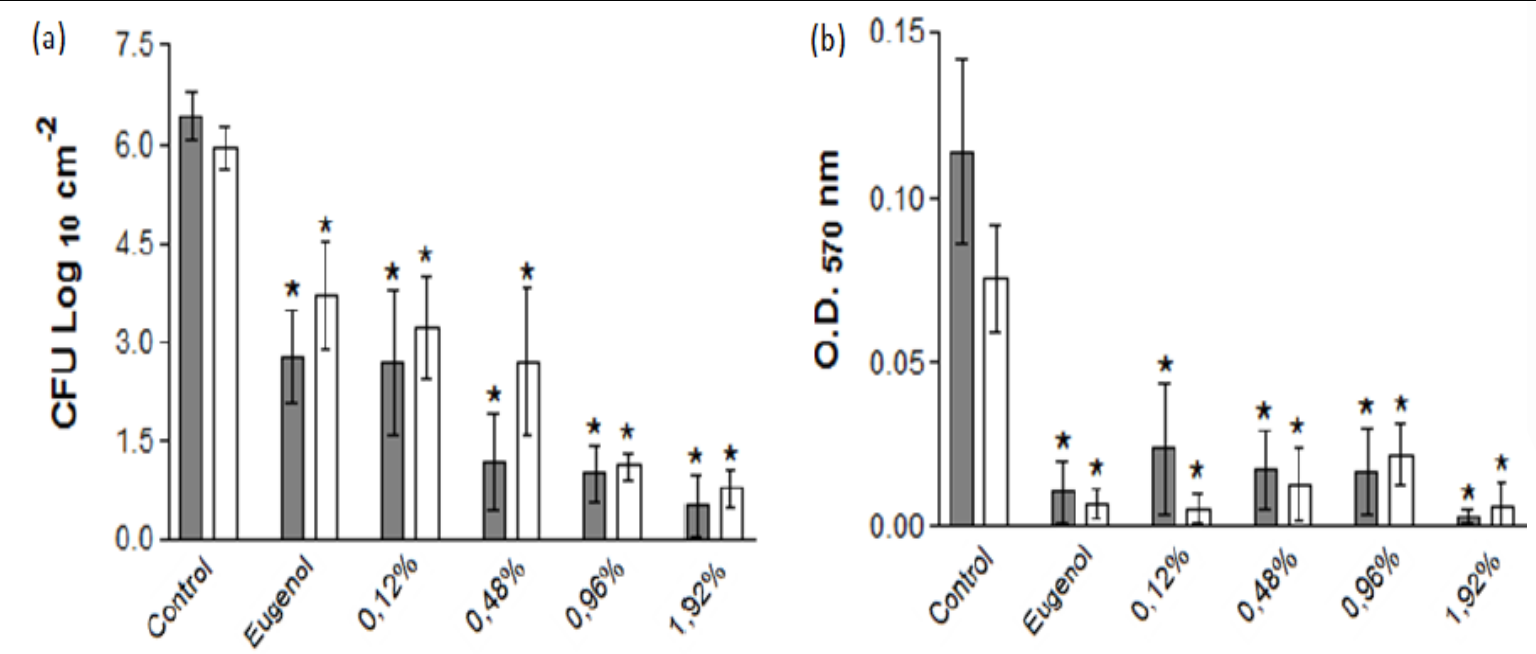

Escherichia coli $\square$ Staphylococcus aureus

Figure 1 - Anti-biofilm potential essential oil cinnamon and eugenol on cultivable cells (a) and biomass (b) Escherichia coli and Staphylococcus aureus. The values are means of three separate assays, and the bars indicate standard deviation. ${ }^{*} \mathrm{P}<0.05$ in one-way analysis of variance test.

of $5.91 \log \mathrm{CFUcm}^{-2}(92.0 \%)$ (Figure 1A). The Staphylococcus aureus was susceptible to the action of eugenol and OE, all treatments were significant $(\mathrm{P}<0.05)$ (Figure 1A). Eugenol reduced 2.2log $\mathrm{CFUcm}^{-2}$; however, the concentration $1.92 \%$ was the best result (reduction of $5.17 \log \mathrm{CFUcm}^{-2}$ ) corresponding to $87.0 \%$ (Figure 1A).

The effect of compound eugenol on the formation of biofilm bacterial biomass was satisfactory $(\mathrm{P}<0.05)$. Escherichia coli was more susceptible at a concentration of $1.92 \%$ with $97.45 \%$ reduction in biomass (Figure 1B). At the concentration of $0.12 \%$, there was $93.0 \%$ reduction of the formation of biomass S. aureus (Figure 1B). There was no concentration-dependent effect on the activity of the EO on biomass produced by $S$. aureus and $E$. coli, increasing concentrations did not reduce the formation of biomass.

Eugenol and EO agents were effective as sanitizers against biofilms formed by $E$. coli and

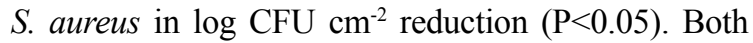
bacteria were less susceptible to treatment with eugenol, a reduction of $1.85 \log \mathrm{CFUcm}^{-2}$ for $E$. coli

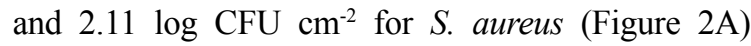
.The greatest reduction of $E$. coli concentration was $1.92 \%$ of EO, $3.85 \log \mathrm{CFUcm}^{-2}$ (64.27\%) (Figure 2). Simultaneously, we observed concentration-dependent effect in which, the higher the concentration used, the greater was the reduction of $\log \mathrm{CFUcm}^{-2}$ of cells of $E$. coli. However, the treatment against $S$. aureus no effect concentration dependent, the greatest reduction was in the concentration of $0.48 \%$ of $\mathrm{EO}$, of 3.46 $\log \mathrm{CFUcm}^{-2}(61.34 \%)$. For biomass formed, all treatments showed poor removal capacity without significant results $(\mathrm{P}>0.05)$ (Figure 2B).

Biofilms are communities on the surfaces of harmful food industries. Thus, there is a high probability that the irreversibly adhered cells will remain even in the surfaces after sanitation. This is one of the main reasons for biofilm formation on surfaces in contact with food. The $C$. zeylanicum EO and its major constituent eugenol are effective antimicrobials with broad-spectrum anti-biofilm and sanitizer activity.

In the food industry, considerable number of surfaces such as stainless steel, glass, low density polyethylene, cast iron, rubber, polycarbonate and polypropylene, are susceptible to microbial adhesion. However, the surface characteristics, such as electric charge, water retention capacity, free energy and topography play an important role in the accession process. In a study the authors mentioned that the cells adhere better on hydrophilic surfaces (stainless steel, glass) than on hydrophobic surfaces (rubber and 

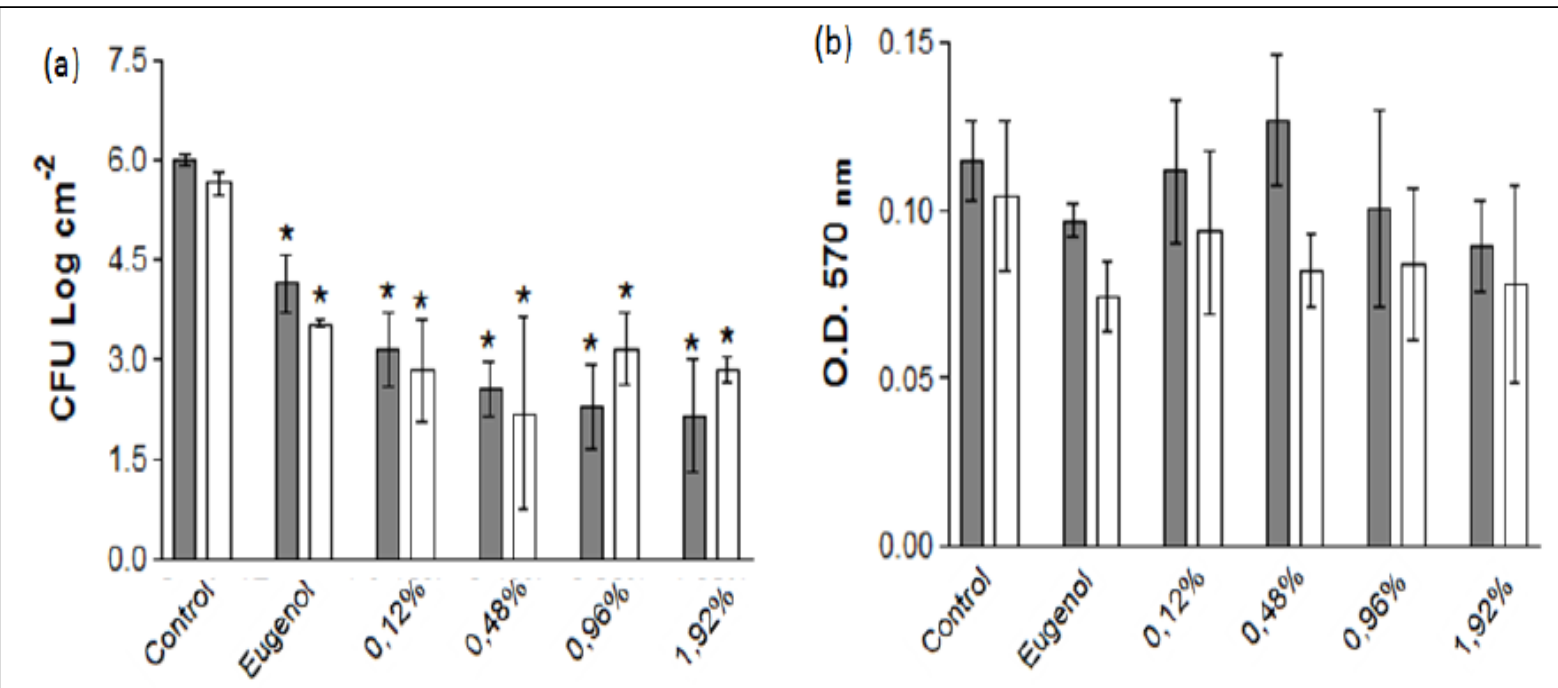

Escherichia coli $\square$ Staphylococcus aureus

Figure 2 - Sanitizer potential cinnamon essential oil and eugenol on Escherichia coli and Staphylococcus aureus cultivable cells in simple biofilms (a) and biomass (b). The values are means of three separate assays, and the bars indicate standard deviation. ${ }^{*} \mathrm{P}<0.05$ in one-way analysis of variance test.

plastics) (STEPANOVIC'et al., 2000). Several other bacteria readily form biofilms on stainless steel surface (MILLEZI et al., 2012). In the present study, it was found that 24 hours was sufficient for the formation of biofilms of $E$. coli and $S$. aureus on stainless steel coupons.

In studies that evaluate the antibacterial potential of different agents, it is common for authors to use both gram-negative and grampositive bacterial strains, which usually have different susceptibility profiles. Normally, gram-negative bacteria, such as E. coli, are more resistant than gram-positive bacteria because their outer membrane serves as an additional barrier making the diffusion of the constituents of the EOs into the bacterial cell difficult (BURT, 2004). The nucleus and the $\mathrm{O}$ antigen in the lipopolysaccharide of the outer membrane of gram-negative bacteria are hydrophilic, which prevents the accumulation of EOs in the cytoplasmic membrane (PSALTIS et al., 2007). In this study, E. coli was more sensitive to the action of the antibacterial activity anti-biofilm; however, the activity sanitizer; E. coli was more resistant than $S$. aureus. This demonstrated that it is important to conduct tests in different situations or stages of biofilm because the bacterial behavior against stress caused by sanitizing agents is versatile.

Disinfectants effectiveness is frequently determined by the number of surface-adhered cells they are capable to reduce, obtained by standard plate count. In present study, beyond the standard plate count was performed to quantify biomass biofilm. Results of the activity of anti-biofilm all treatments were unsatisfactory $(\mathrm{P}>0.05)$, however, when eugenol and $\mathrm{EO}$ were used as sanitizers, already formed biofilm by 24 hours, there were significant biomass reductions. Once formed, biofilms showed greater power of resistance to treatments.

In the research BURT (2004) examined the anti-biofilm activity of EOs some of their major constituents on biofilms formed by $S$. aureus and $E$. coli on the surface of medical biomaterials. Melaleuca alternifolia and Melissa officinales OEs, as well as constituents alpha-terpineol and terpinen4-ol, showed high activity anti-biofilm. According to these same authors, the death rate of biofilm formed by $S$. aureus within 24 hours, treated with EOs and its constituents, said partial reduction $(50 \%)$ of the biomass metabolism. Concentrationdependent effect was observed for E. coli biofilm; 
however, was more susceptible to the action of the treatments that biofilms of $S$. aureus. Results of this study are similar to those obtained (BURT, 2004), there was a high biomass reduction of both biofilms. Furthermore, E. coli was also more susceptible to anti-biofilm activity and decreased concentration dependent EO treatment.

Satisfactory results were obtained with reduction of $\log \mathrm{CFU}$ in treated and biomass EO C. zeylanicum and its major compound isolated eugenol. However, the highest concentrations of EO $(0.96 \%$ and $1.92 \%)$ logarithmic reduction was more significant $(\mathrm{P}>0.05)$. Previous studies have shown that the antimicrobial effect of essential oils is due to the interaction between all the essential oil components present and not due to an individual component (NEU et al., 2010). In research SIMIC et al. (2004) reported the use of a single EOs majority components to treat a biofilm in this study was not sufficient to inhibit biofilm growth. However, in this study, eugenol was effective except as a sanitizing agent in removal of biofilms formed by biomass.

Mechanism of action against bacteria is yet not fully understood, but it is speculated to involve membrane disruption through lipophilic products. (MILLEZI et al., 2016). Phenolic compounds, such as eugenol, can cause the disruption of energy production due to enzyme inhibition by the oxidized products, through reaction with sulfhydyl groups or through more nonspecific interactions with proteins (MENDOZA et al.,1997).

In this research, we obtained important findings, we found that the use of EO $C$. zeylanicum and eugenol may be a promising alternative, especially as anti-biofilm agent to prevent or reduce the formation of biofilms of $E$. coli and $S$. aureus on surfaces of stainless steel AISI 304. However, the effectiveness of treatments against biofilms does not always lead to its total destruction and eradication.

\section{DECLARATION OF CONFLICTING INTERESTS}

There is no conflict of interest.

\section{ACKNOWLEDGEMENTS}

Conselho Nacional de Desenvolvimento Científico e Tecnológico (CNPq), Coordenação de Aperfeiçoamento de Pessoal de Nível Superior (CAPES), Fundação de Amparo à Pesquisa do Estado de Minas Gerais
(FAPEMIG) and Foundation for Science and Technology and European Community fund European Regional Development Fund (FEDER), in the ambit of the Project PTDC/ SAUESA/6460912006/FCOMP-01-0124-FEDER-007480.

\section{AUTHORS' CONTRIBUTIONS}

All authors contributed equally for the conception and writing of the manuscript. All authors critically revised the manuscript and approved of the final version.

\section{REFERENCES}

BAKKALIA, F. Biological effects essential oils: A review. Food and Chemical Toxicology, v.46, p.446-475, 2008. Available from: $<$ https://www.sciencedirect.com/science $>$. Accessed: Jan. 15, 2017. doi: 10.1016/j.fct.2007.09.106.

DIAS, C. et al. Biofilm formation and multidrug-resistant Aeromonas spp. from wild animals. Journal of Global Antimicrobial Resistance v. 12 227-234, 2018. Available from: <https://www. sciencedirect.com/science/article/pii/S2213716517301765>. Accessed: Aug. 07, 2018. doi:10.1016/j.jgar.2017.09.010.

BURT, S. Essential oils: their antibacterial properties and potential applications in foods: a review. International Journal of Food Microbiology, v.94, p.223-253, 2004. Available from: <https:// www.sciencedirect.com/science/article/pii/S0168160504001680>. Accessed: Dec. 16, 2017. doi: 10.1016/j.ijfoodmicro.2004.03.022.

DONLAN, R. M. Biofilms: Microbial Life on Surfaces. Emerging Infectious Diseases, v. 8, p.881-890, 2002. Available from: <https://wwwnc.cdc.gov/eid/>. Accessed: Jun. 22, 2018. doi: 10.3201/eid0809.020063.

FROZI, J. B. et al. Single- and Multispecies Biofilms by Escherichia coli, Staphylococcus aureus, and Salmonella spp. Isolated from Raw Fish and a Fish Processing Unit. Ciência Rural, v. 47, p. 1-6, 2017. Available from: <http://www.scielo.br/ scielo.php?script $=$ sci_arttext\&pid $=$ S0103-84782017001000451>. Accessed: Aug. 07, 2018. doi: 10.1590/0103-8478cr20170011.

HERIGSTAD, B. et al. How to optimize the drop plate method for enumerating bacteria. Journal Microbiology Methods, v.44, p. 121-129, 2001. Available from: <https://www.ncbi.nlm.nih.gov/ pubmed/11165341>. Accessed: Jun. 14, 2018. doi: 10.1016/S01677012(00)00241-4.

KAWARAI, T. et al. Biofilm formation by Escherichia coli in hypertonic sucrose media. Journal of Bioscience and Bioengineering, v.107, p.630-635, 2009. Available from: <https:// www.sciencedirect.com/science/article/pii/S1389172309000620>. Accessed: Dec. 16, 2017. doi: 10.1016/j.jbiosc.2009.01.018.

MENDOZA, L. et al. Antimicrobial study of the resinous exudates and of diterpenoids and flavonoids isolated from some Chilean Pseudognaphalium (Asteraceae). Journal of Ethnopharmacology, v.58, p.85-88, 1997. Available from: <https://www.sciencedirect. com/science/article/pii/S0378874197000846>. Accessed: Dec. 15, 2017. doi: 10.1016/S0378-8741(97)00084-6.

MENON, K. V. Biofilm and food industry. International Journal of Advanced Research in Biological Sciences, v.4, p.137-142, 2016. Available from:<http://www.ijarbs.com>. Accessed: Dec. 16, 2017 .doi: 1.15/ijarbs-2016-3-4-19. 
MILLEZI, A. F. et al. Reduction of Aeromonas hidrophyla biofilm on stainless stell surface by essential oils. Brazilian Journal of Microbiology, v.44, p.73-80, 2013. Available from: <http://www. scielo.br/scielo>. Accessed: Dec. 15, 2017. doi: 10.1590/S151783822013005000015 .

MILLEZI, A. F. et al. Susceptibility of mono and dual-species biofilms of Staphylococcus aureus and Escherichia coli to essential oils. Journal of Food Safety, v.32, p.351-359, 2012. Available from: $<$ https://onlinelibrary.wiley.com $>$. Accessed: Dec. 15, 2017. doi: 10.1590/S1516-05722013000300010.

MILLEZI, A. F. et al. Anti-biofim and Antibacterial Effect of Essential Oils and Their Major Compounds. Journal of Essential Oil Bearing Plants, v.19, p.624-631, 2016. Available from: $<$ http://repositorium.sdum.uminho.pt $>$. Accessed: Dec. 18, 2017. doi: 10.1080/0972060X.2014.960262.

NEU, T. R. et al. Advanced imaging techniques for assessment of structure, composition and function in biofilm systems. FEMS Microbiology Ecology, v.72, p.1-21, 2010. Available from: <https://academic.oup.com/femsec/article/72/1/1/554038>. Accessed: Dec. 14, 2017. doi: 10.1111/j.1574-6941.2010.00837.x.

OUSSALAH, M. et al. Mechanism of action of Spanish oregano, Chinese cinnamon, and savory essential oils against cell membranes and walls of Escherichia coli O157:H7 and Listeria monocytogenes. Journal of Food Protection, v.69, p.1046-1055 2007. Available from: <http://jfoodprotection.org/doi/pdf $>$. Accessed: Dec. 15, 2017. doi: 10.4315/0362-028X-69.5.1046.

PARIZZI, S. Q. F. et al. Bacterial adherence to different inert surfaces evaluated by epifluorescence microscopy and plate count method. Brazilian Archives of Biology Technology, v. 47, p. 7783, 2004. Available from: $<$ http://www.scielo.br/scielo $>$. Accessed: Jan. 01, 2018. doi: 10.1590/S1516-89132004000100011.

PSALTIS, A. J. et al. Confocal scanning laser microscopy evidence of biofilms in patients with chronic rhinosinusitis. Laryngoscope, v. 117, p.1302-1306, 2007. Available from: <https://onlinelibrary.
wiley.com/doi/pdf/10.1097/MLG.0b013e31806009b0>. Accessed: Dec. 16, 2017. doi: 10.1097/MLG.0b013e31806009b0.

ROGER S. R.; HUIGENS, R. W.; CAVANAGH, J.; MELANDER, C. Synergistic Effects between Conventional Antibiotics and 2-Aminoimidazole-Derived Antibiofilm Agents. Antimicrob Agents Chemother, v. 54, p. 2112-2118, 2010. Available from: $<$ https://www.ncbi.nlm.nih.gov/pmc/articles/PMC2863642>. Accessed: Aug. 09, 2018. doi: 10.1128/AAC.01418-09.

SZCZEPANSKI, S.; LIPSKI, A. Essential oils show specific inhibiting effects on bacterial biofilm formation. Food Control, v. 36. p. 224-229., 2014. Available from: <https://www.sciencedirect. com/science/article/pii/S0956713513004155?via\%3Dihub>. Accessed: Aug. 07, 2018. doi: 10.1016/j.foodcont.2013.08.023.

SIMIC, A. et al. The chemical composition of some Lauraceae essential oils and their antifungal activities. Research Article, v.18, p.713-717, 2005. Available from: <https://onlinelibrary. wiley.com/doi/full/10.1002/ptr.1516>. Accessed: Dec. 16, 2017. doi: $10.1080 / 08927010500066982$.

STEPANOVIC', S. et al. A modified microtiter-plate test for quantification of staphylococcal biofilm formation. Journal of Microbiological Methods, v.40, p.175-179, 2000. Available from: <https://www.sciencedirect.com/science/ article/pii/S0167701200001226>. Accessed: Dec. 16, 2017. doi: 10.1016/S0167-7012(00)00122-6.

XIAOFENG Z. et al. In Vitro Evaluation of Antioxidant and Antimicrobial Activities of Melaleuca alternifolia Essential Oil. Bio Med Research International. v. 1 2018, p. 1-8 p. Available from: <https://www.hindawi.com>. Accessed: Jun. 22, 2018. doi: $10.1155 / 2018 / 2396109$.

WANG, R. et al. Extraction of essential oils from cinnamon leaves and identification of their volatile compositions. Innovative Food Science \& Emerging Technologies, v.10, p.289-292, 2009. Available from: <https://www.sciencedirect.com>. Accessed: Dec.16, 2017.doi: 10.1016/j.ifset.2008.12.002. 